\title{
Assessment of Glutathione Peroxidase-1 (GPX1) Gene Expression as a Specific Diagnostic and Prognostic Biomarker in Malignant Pleural Mesothelioma
}

\author{
Amal F. Gharib ${ }^{1,+}$, Muhammad Alaa Eldeen ${ }^{2, *,+} \mathbb{0}$, Amany Salah Khalifa ${ }^{3}$, Wael H. Elsawy ${ }^{4} \mathbb{D}$, \\ Emad Mohamed Eed ${ }^{1}$, Ahmad El Askary ${ }^{1}$, Refaat A. Eid ${ }^{5} \oplus$, Mohamed A. Soltan ${ }^{6}{ }^{\circ}$ and Nermin Raafat ${ }^{7}$ \\ 1 Department of Clinical Laboratory Sciences, College of Applied Medical Sciences, Taif University, \\ P.O. Box 11099, Taif 21944, Saudi Arabia; amgharib@tu.edu.sa (A.F.G.); e.eed@tu.edu.sa (E.M.E.); \\ a.elaskary@tu.edu.sa (A.E.A.) \\ 2 Cell Biology, Histology, Genetics Division, Zoology Department, Faculty of Science, Zagazig University, \\ Alsharquia 44519, Egypt \\ 3 Department of Clinical Pathology, Faculty of Medicine, Menoufia University, Menoufia 32511, Egypt; \\ dramanisalah@yahoo.com \\ 4 Department of Clinical Oncology, Faculty of Medicine, Zagazig University, Zagazig 44519, Egypt; \\ whelsawy@gmail.com \\ 5 Department of Pathology, College of Medicine, King Khalid University, Abha 12573, Saudi Arabia; \\ refaat_eid@yahoo.com \\ Citation: Gharib, A.F.; \\ Alaa Eldeen, M.; Khalifa, A.S.; \\ Elsawy, W.H.; Eed, E.M.; Askary, A.E.; \\ 6 Department of Microbiology and Immunology, Faculty of Pharmacy, Sinai University, \\ Ismailia 41611, Egypt; mohamed.mohamed@su.edu.eg \\ 7 Department of Medical Biochemistry, Faculty of Medicine, Zagazig University, Zagazig 44519, Egypt; \\ nerminraafat@gmail.com \\ * Correspondence: muhammadalaaeldeen@zu.edu.eg; Tel.:+20-1090036420 \\ + These authors are equally contributed to this work.
} Eid, R.A.; Soltan, M.A.; Raafat, N. Assessment of Glutathione Peroxidase-1 (GPX1) Gene Expression as a Specific Diagnostic and Prognostic Biomarker in Malignant Pleural Mesothelioma. Diagnostics 2021, 11, 2285. https://doi.org/ $10.3390 /$ diagnostics11122285

Academic Editor: Renzo Boldorini

Received: 25 November 2021

Accepted: 1 December 2021

Published: 7 December 2021

Publisher's Note: MDPI stays neutral with regard to jurisdictional claims in published maps and institutional affiliations.

Copyright: (c) 2021 by the authors. Licensee MDPI, Basel, Switzerland. This article is an open access article distributed under the terms and conditions of the Creative Commons Attribution (CC BY) license (https:/ / creativecommons.org/licenses/by/ $4.0 /)$.
Abstract: Malignant pleural mesothelioma (MPM) is a malignant tumor of the mesothelial lining of the thorax. It has been related to frequent exposure to asbestos. Diagnosis of malignant pleural mesothelioma is considered a criticizing problem for clinicians. Early diagnosis and sufficient surgical excision of MPM are considered the cornerstone success factors for the management of early MPM. Glutathione peroxidase-1 (GPX1) is an intracellular protein found to be extensively distributed in all cells, and it belongs to the GPX group. In the current study, we included ninety-eight patients with MPM that underwent surgery at the Zagazig University Hospital in Egypt. We assessed GPX1 gene expression level as it was thought to be related to pathogenicity of cancer in a variety of malignant tumors. We observed a significant elevation in GPX1-mRNA levels in MPM relative to the nearby normal pleural tissues. It was found to be of important diagnostic specificity in the differentiation of MPM from normal tissues. Moreover, we studied the survival of patients in correlation to the GPX1 expression levels and we reported that median overall survival was about 16 months in patients with high GPX1 expression levels, while it was found to be about 40 months in low GPX1 levels.

Keywords: malignant pleural mesothelioma; GPX1; gene expression; diagnostic biomarker

\section{Introduction}

Malignant pleural mesothelioma (MPM) is a neoplasm caused by asbestos exposure and originates in the mesothelial lining of the thoracic cavity [1]. MPM is a fatal tumor; its prognosis is marginally impacted by the current cancer treatments [2]. It represents a critical problem for clinicians in its diagnosis and treatment. MPM is usually presented in late stages with a median survival of less than one year [3]. Early diagnosis and adequate treatment prove to remain the predominant factors in the treatment of early MPM. However, until now, there are no dependent and accurate biomarkers for its detection and diagnosis; at the time of diagnosis, nearly all cases have advanced or metastatic tumors [4]. 
The glutathione peroxidase (GPX) is one of the groups of the phylogenetic trees associated enzymes. GPX is involved in numerous vital biological processes. GPX induces $\mathrm{H}_{2} \mathrm{O}_{2}$ reduction and glutathione (GSH) oxidation that can be reduced again by GPX reductase via NADPH [5]. GPX1, a widely released component of the GPX group, is an intracellular protein extensively distributed in all cells [6]. The expression of GPX1 is directly linked with malignant transformation and tumor spread. It has been observed in many types of malignancies [7].

Interestingly, literature also showed a significant impact of GPX1 on the inhibition of malignant transformation by reducing the oxidative DNA mutations during the initiation of the transformation process [8]. One study reported that GPX1 overexpression inhibited the proliferation of malignant pancreatic cell lines [9]. Baliga et al. observed that GPX1 knockdown in prostate cancer cells enhanced the radiotherapy effect by increasing the formation of micronuclei [10]. Higher GPX1 expression, on the other hand, was associated with substantial penetration of the blood vessels and low survival in hepatocellular carcinoma and oral squamous cell carcinoma [11,12].

Considering the data described earlier, GPX1 may have a protective or injurious biological function depending on the type of malignant tumor. The role of GPX1 in malignancy remains relatively unclear, requiring further research, especially on the relationship between GPX1 and the clinical outcome. In MPM, the role of GPX1 and its function was not previously studied; therefore, we conducted this research to evaluate its role and its diagnostic and prognostic capability in MPM.

\section{Materials and Methods}

Ninety-eight patients with locally or early advanced MPM participated in this study. Most of patients were surgically resectable. Patients did not receive neoadjuvant therapy before surgery. They were surgically operated at the Zagazig University Hospital, Egypt, during the period from March 2014 to December 2020. Informed consent was obtained from all included patients and approval of the study was obtained from the ethical committees of the Zagazig University. All patients were clinically staged according to the eighth edition manual of the American Joint Committee of Cancer (AJCC) [13]. The performance status of all patients was assessed using the Zubord Scale [14].

\subsection{Tissue Specimens}

Tissue specimens were obtained from the frozen specimens collected from the malignant and the adjacent normal pleural tissues (ANPT) excised during surgery.

\subsection{RNA Isolation}

Total RNA was extracted from 50-100 mg of grounded frozen tissue specimens by the miRNeasy Mini Kit (QIAGEN, Hilden, Germany) in compliance with the supplier's instructions. Each sample was put in $600 \mu \mathrm{L}$ RNA lysis buffer (Promega, Madison, Wisconsin) until complete digestion of the tissues occurred. The final extracted RNA volume was $40 \mu \mathrm{L}$.

\subsection{Synthesis of Complementary DNA ( $c D N A)$}

The extracted RNA was reverse transcribed to synthesize cDNA by iNtRON Biotechnology, cat No 25011, Korea, in compliance with their manual.

\subsection{GPX1 Gene Expression Analysis by RT-qPCR}

The quantitative real-time polymerase chain reaction (RT-qPCR) was carried out by SYBR Green PCR Master Mix (Perfect Real Time; TaKaRa Biotechnology, Shiga, Japan) using StratageneMx3005P-qPCR system. The amplification reaction was performed using $20 \mu \mathrm{L}$ of a mixture composed of $5 \mu \mathrm{L} \mathrm{cDNA}, 10 \mu \mathrm{L}$ SYBR Green master mix, and $100 \mathrm{pmol} / \mathrm{ul}$ of the primers. The $\beta$-actin gene was utilized for internal control. We used the following primers: GPX1 forward primer $\left(5^{\prime}-3^{\prime}\right)$ : GTG CTC GGC TTC CCG TGC AAC and reverse primer $\left(5^{\prime}-3^{\prime}\right)$ : 
CTC GAA GAG CAT GAA GTT GGG C; $\beta$-actin forward primer $\left(5^{\prime}-3^{\prime}\right)$ : CAC CAT TGG CAA TGA GCG GTT C; and the reverse primer $\left(5^{\prime}-3^{\prime}\right)$ : AGG TCT TTG CGG ATG TCC ACG T.

All tests were utilized and measured in duplicate and normalized to the levels of $\beta$-actin. The GPX1gene expression fold change was quantitated by the $2^{-\Delta \Delta C t}$ method [15].

\subsection{Statistical Analysis}

Quantitative data were expressed as the mean \pm standard deviation and compared using the Student's ( $t$-test) and one-way analysis of variance (ANOVA). $p<0.05$ was deemed significant. The capability of GPX1 gene expression to differentiate between malignant and healthy tissue was analyzed by plotting receiver operating characteristics curve (ROC), which relates the true positive (sensitivity) to the false positive (specificity), and by computing area under the curve (AUC). Survival was evaluated by the KaplanMeier curve. All statistical estimates were carried out by SPSS version 23.0 (SPSS Inc., Chicago, IL, USA).

\section{Results}

\subsection{GPX1-mRNA Levels in MPM and Their ANPT}

The GPX1-mRNA levels were significantly elevated in MPM relative to ANPT; in MPM it ranged between 1.2 to $9.09\left(2^{-\Delta \Delta \mathrm{Ct}}\right)$ with a mean value of 7.001 , while in ANPT it ranged between 0.005 and 0.92 with a mean value 0.31 . This variation was statistically significant (Student's $t$-test, $\mathrm{t}=31.87, p<0.0001$ ) (Figure 1A).

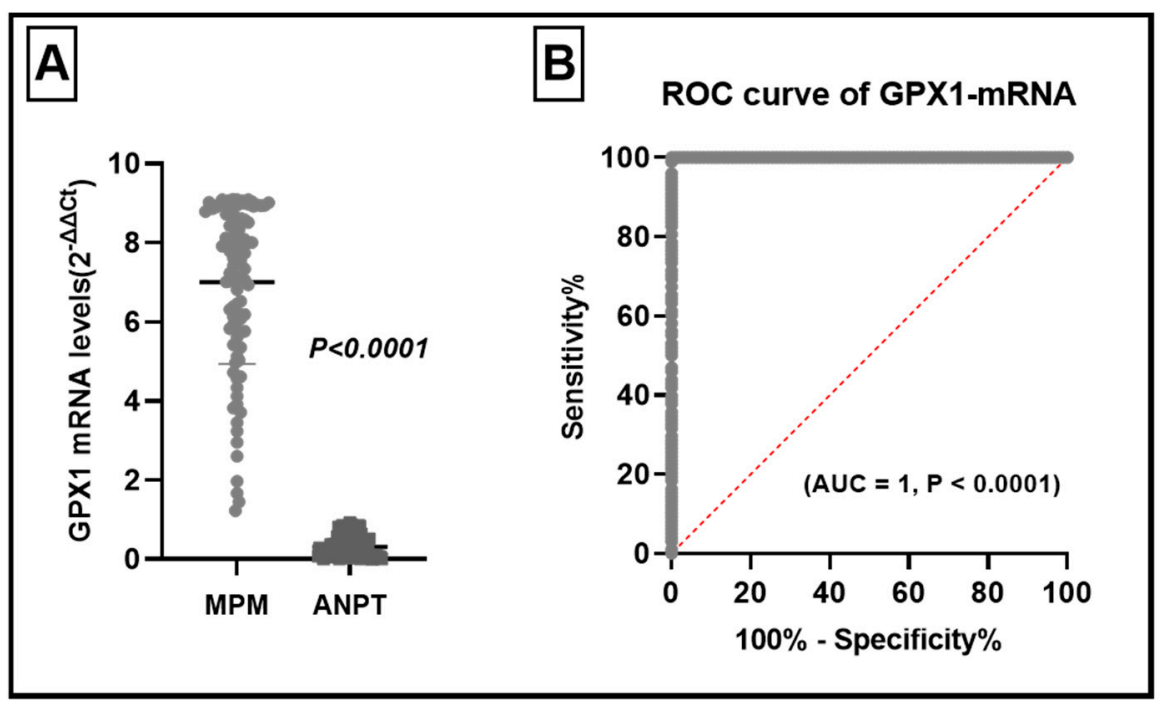

Figure 1. GPX1 levels in malignant pleural mesothelioma (MPM) and their adjacent normal pleural tissues (ANPT). (A) GPX1-mRNA levels were significantly higher in MPM $(\mathrm{t}=31.87, p<0.0001)$. (B) ROC curve analysis of levels of GPX1-mRNA in MPM and ANPT, with high ability to distinguish MPM (AUC $=1.95 \%, C I: 1.000$ to $1.000, p<0.0001)$.

To find out if the high levels of GPX1-mRNA have a diagnostic specificity for MPM, we plotted the receiver operating characteristic (ROC) curve. The ROC curve study revealed that GPX1-mRNA could accurately differentiate MPM tissues from normal pleural tissues with an area under the curve (AUC) of 1.95\% (CI: 1.000 to 1.000, $p<0.0001$ ) (Figure 1B).

\subsection{Clinical Significance of Elevated GPX1-mRNA Levels in MPM}

We probed the elevated GPX1 levels and different prognostic, clinical, and pathological features. Elevation of GPX1 levels were noted in older patients $>55$ years $(p<0.0001)$, female patients $(p<0.0001)$, non-epithelioid histopathological type $(p<0.0001)$, high grade tumors $(p<0.0001)$, large tumors $(p<0.0001)$, lymph node involvement $(p<0.0001)$, advanced stage II clinical stage $(p<0.0001)$, patients with anemia $(p<0.0001)$, patients 
with increased platelet counts, white blood cells and LDH levels $(p<0.0001)$. The bad performance status (PS) of the patient was significantly related to the elevation of GPX1mRNA levels $(p<0.0001)$. Unrespectability of the primary tumors were also found to be associated with high GPX1-mRNA levels $(p<0.0001)$ (Table 1). Elevated GPX1-mRNA levels were found to be linked to adverse prognostic and clinical features.

Table 1. The relation between GPX1-mRNA levels and different prognostic, clinical, and pathological features.

\begin{tabular}{|c|c|c|c|c|}
\hline & \multicolumn{4}{|c|}{ GPX1 mRNA Level } \\
\hline & No & Mean & SD & $p$ \\
\hline \multicolumn{5}{|c|}{ Age } \\
\hline$\leq 55$ years & 58 & 5.769 & 1.836 & \multirow{2}{*}{$<0.0001 *$} \\
\hline$>55$ years & 40 & 8.789 & 0.33 & \\
\hline \multicolumn{5}{|c|}{ Sex } \\
\hline Males & 44 & 5.157 & 1.693 & \multirow{2}{*}{$<0.0001 *$} \\
\hline Females & 54 & 8.504 & 0.571 & \\
\hline \multicolumn{5}{|c|}{ Pathology } \\
\hline Epithelioid & 66 & 6.065 & 1.899 & \multirow{2}{*}{$<0.0001 *$} \\
\hline Non-Epithelioid & 32 & 8.932 & 0.1485 & \\
\hline \multicolumn{5}{|c|}{ Histopathological grade } \\
\hline G1-G2 & 35 & 4.67 & 1.56 & \multirow{2}{*}{$<0.0001 *$} \\
\hline G3-G4 & 63 & 8.297 & 0.737 & \\
\hline \multicolumn{5}{|c|}{ Tumor Resection } \\
\hline Complete & 37 & 4.79 & 1.60 & \multirow{3}{*}{$<0.0001 * *$} \\
\hline Partial & 49 & 8.17 & 0.68 & \\
\hline Unresectable & 12 & 9.06 & 0.03 & \\
\hline \multicolumn{5}{|c|}{$\mathrm{T}$} \\
\hline $\mathrm{T} 1$ & 72 & 6.282 & 1.956 & \multirow{3}{*}{$<0.0001$ * } \\
\hline $\mathrm{T} 2$ & 26 & $\begin{array}{l}0.202 \\
8.993\end{array}$ & 0.075 & \\
\hline $\mathrm{T} 3$ & 26 & 8.993 & 0.075 & \\
\hline \multicolumn{5}{|c|}{$\mathrm{N}$} \\
\hline N1 & 72 & 6.282 & 1.956 & \multirow{2}{*}{$<0.0001$ * } \\
\hline $\mathrm{N} 2$ & 26 & 8.993 & 0.075 & \\
\hline \multicolumn{5}{|c|}{ Stage } \\
\hline $\mathrm{I}$ & 39 & 8.81 & 0.308 & \multirow{2}{*}{$<0.0001 *$} \\
\hline II & 59 & 5.81 & 1.84 & \\
\hline \multicolumn{5}{|c|}{$\mathrm{Hb} \%$} \\
\hline$<14$ gm & 56 & 5.69 & 1.819 & \multirow{2}{*}{$<0.0001$ * } \\
\hline$>14 \mathrm{gm}$ & 42 & 8.75 & 0.366 & \\
\hline \multicolumn{5}{|c|}{ Platelet Count } \\
\hline Normal & 46 & 5.253 & 1.717 & \multirow{2}{*}{$<0.0001^{*}$} \\
\hline High & 52 & 8.548 & 0.536 & \\
\hline \multicolumn{5}{|c|}{ WBCs } \\
\hline Normal & 57 & 5.729 & 1.827 & \multirow{2}{*}{$<0.0001^{*}$} \\
\hline High & 41 & 8.77 & 0.3483 & \\
\hline \multicolumn{5}{|c|}{$\mathrm{LDH}$} \\
\hline Normal & 72 & 6.28 & 1.96 & \multirow{2}{*}{$<0.0001$ * } \\
\hline High & 26 & 8.99 & 0.075 & \\
\hline & & rmance & & \\
\hline $0-1$ & 72 & 6.28 & 1.96 & \\
\hline 2 & 26 & 8.99 & 0.075 & $<0.0001$ \\
\hline
\end{tabular}

*Student's t-test, ${ }^{* *}$ one way analysis of variance (ANOVA). 


\subsection{The Role of Elevated GPX1- mRNA in the Diagnosis of MPM}

To evaluate the diagnostic role of GPX1-mRNA in MPM, ROC curve was plotted between the GPX1-mRNA levels in the normal pleural tissues and MPM tissues. It revealed a high specificity to the diagnosis of MPM (Figure 1B). We plotted the ROC curve to evaluate the diagnostic significance of a high level of GPX1-mRNA in different clinical and pathological features. We observed that high GPX1-mRNA might be of clinical significance in the diagnosis of $\mathrm{T} 1$ patients/T2 + T3 (Figure 2A, AUC $=1.95 \%$, CI: 1.000 to 1.000, $p<0.0001$ ), grade $1+2$ /grade $3+4$ (Figure $2 \mathrm{~B}, \mathrm{AUC}=1.95 \%$, CI: 1.000 to $1.000, p<0.0001$ ), N1/N2 lymph node infiltration (Figure 2C, AUC $=1.95 \%$, CI: 1.000 to $1.000, p<0.0001$ ), and TNM clinical stage I/II (Figure 2D, AUC $=1.95 \%$, CI: 1.000 to $1.000, p<0.0001$ ).

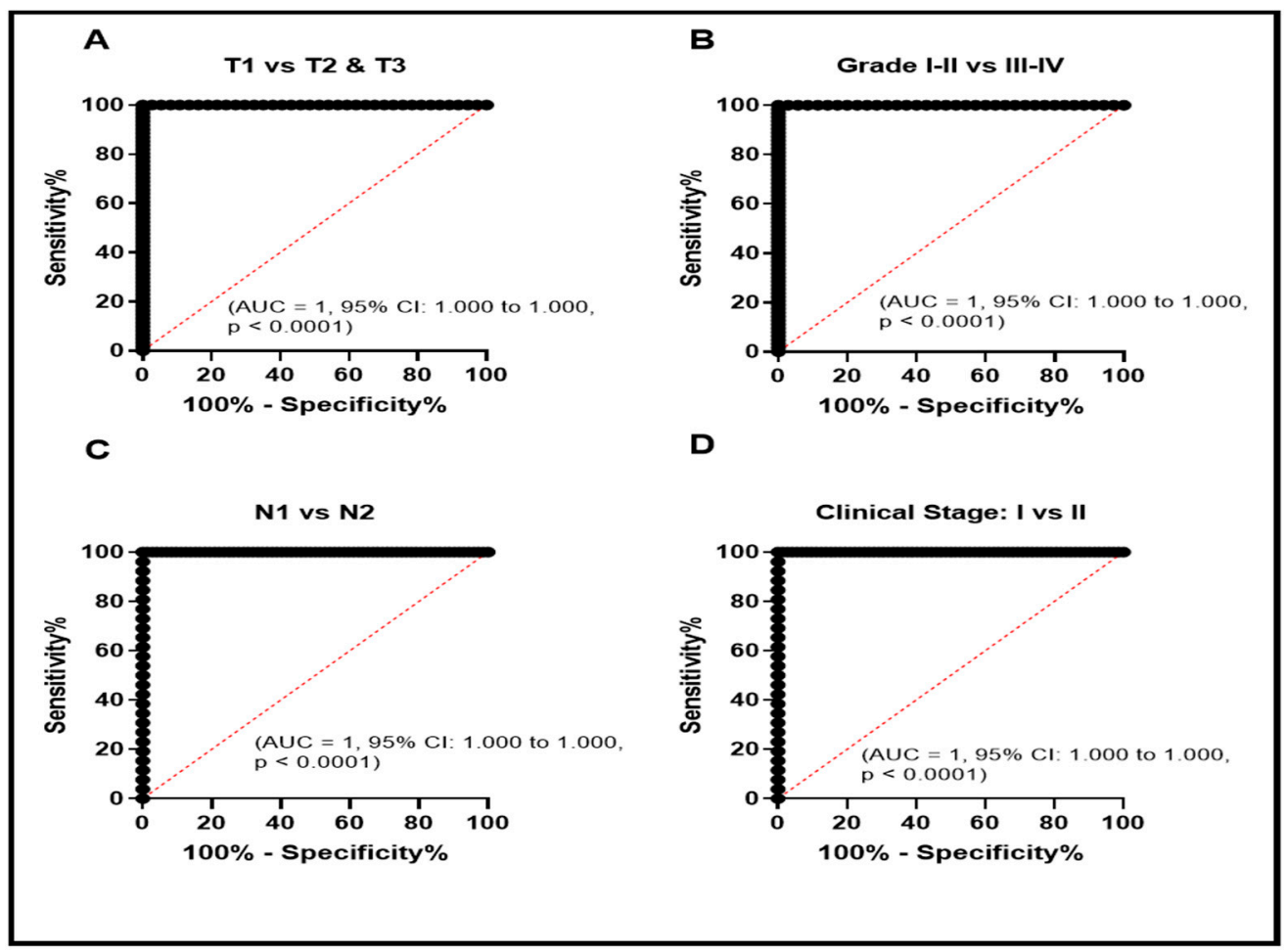

Figure 2. ROC curve evaluation of elevated GPX1-mRNA in patients with MPM with different clinical and pathological data to study its potential role as a diagnostic biomarker. ROC curve study for tumor size (T) (A), pathological grade (B), lymph node infiltration (N) (C), and TNM clinical stage (D).

We studied the survival among our included patients according to the level of GPX1mRNA by plotting the Kaplan-Meier curve (Figure 3). The median survival of the patients with low GPX1-mRNA was 40 months compared to 16 months for the patients with high levels. This difference in survival was statistically significant (Log-rank test 17.59, $p<0.0001$ ). 


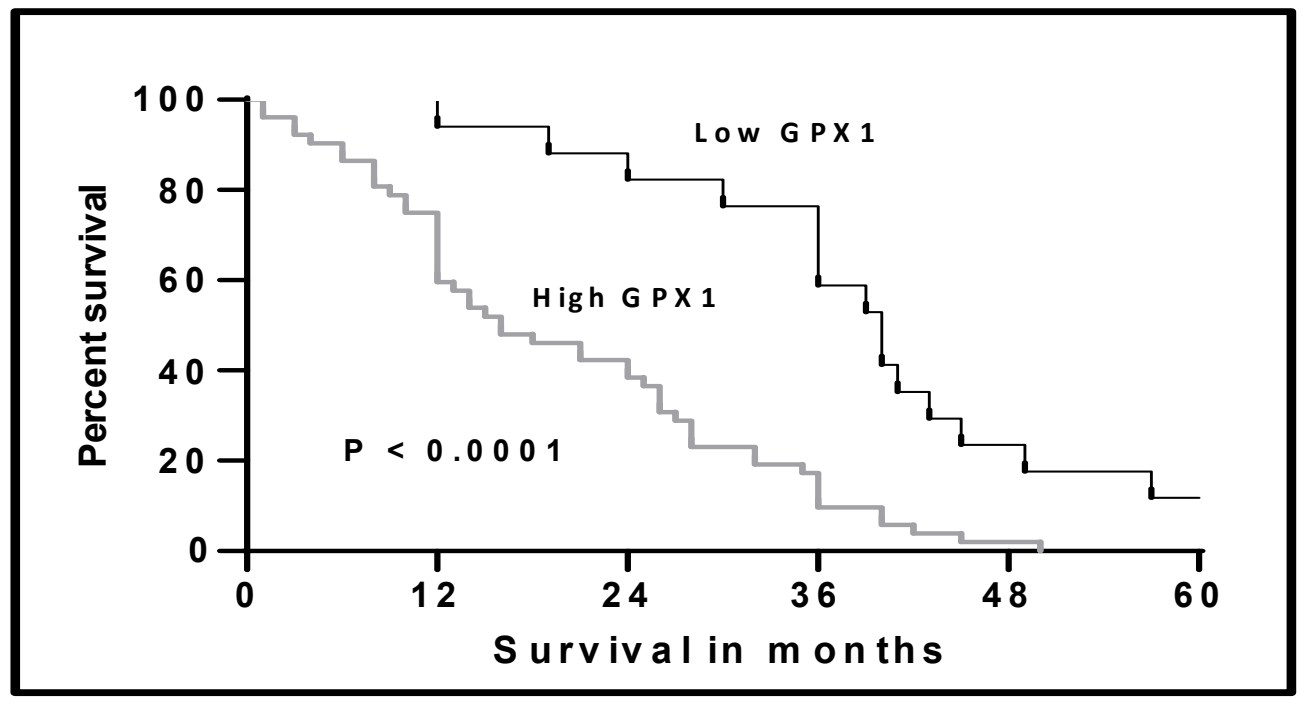

Figure 3. Kaplan-Meier curve of the overall survival in the patients with MPM according to the level of GPX1-mRNA in patients with MPM, Log-rank test $=17.59, p<0.0001$.

\section{Discussion}

Mesothelioma is a fatal malignant tumor related to previous exposure to asbestos, originating from the surface of the pleura and presented in an advanced stage [1]. Early detection and diagnosis of this disease is the cornerstone in the management and the prognosis affected patients [16-18]. Up until now, there are no beneficial biomarkers for early diagnosis of pleural mesothelioma.

During the normal oxidative respiratory process, normal and malignant cells produce reactive oxygen species (ROS) that are eliminated by antioxidant enzymes. These ROS can damage DNA and other cellular organelles [6].

In malignant cells, there is an increase in the metabolic rate and disturbance in the mitochondrial function that results in increased ROS formation [19]. Accumulation of ROS resulted in malignant transformation, development, spread, and the emergence of resistant cells to cytotoxic drugs [20-23].

One of the members of the glutathione peroxidases (GPXs) is the GPX1 found in the cytoplasm and mitochondria. Many authors have reported that GPX1 can perform opposing functions in various cancers.

Elevated GPX1 production in squamous cell carcinoma of the oral cavity and the esophagus induced the tumor growth, spread, vascular infiltration, and resistance to Cisplatinum [12]. On the other side, increased GPX1 levels activated apoptosis in pancreatic carcinoma [24]. The role of GPX1 was not previously studied in MPM. In this research, we aimed to evaluate the function of GPX1 and its diagnostic and prognostic role in MPM.

In the current study, we observed that GPX1-mRNA levels were markedly elevated relative to the nearby normal pleural tissues. We noted that this elevation has a diagnostic specificity to differentiate MPM from normal tissues. Increased GPX1 expression was reported in the head and neck [25], gastric [26], and hepatic and prostatic malignancies [27]. On the other hand, low GPX1 expression was reported in thyroid cancer [28].

In our study, we noted that elevation of GPX1 was found in patients with adverse prognostic features such as old age, female gender, bad performance status, non-epithelioid tumors, undifferentiated tumors, large tumors, lymph node infiltration, unresectable tumors, advanced clinical stage, the presence of anemia, increased platelet and white blood cell counts, and increased serum LDH level.

Our results were also reported by Cheng et al. in renal cell carcinomas; they found that the increased levels of GPX1 were linked to lymph node metastases, advanced stage, and metastatic disease [29]. Lee et al. reported previously that elevated levels of GPX1 were related to adverse clinical features in oral squamous cell carcinomas [12]. On the contrary, in a previous study that 
included patients with gastric cancers, low expression of GPX1 was associated with aggressive tumors [30]. In head and neck squamous cell carcinomas, Dequanter et al. also reported the link between low GPX1 expression and advanced tumor stage [25].

To evaluate the prognostic significance of elevated GPX1 in MPM, we studied the survival of patients according to the GPX1-mRNA levels. The median overall survival was 16 months in patients with high GPX1 levels and 40 months in low GPX1 levels. Lee et al. reported in their series of patients with oral squamous cell carcinoma that high GPX1 levels were associated with short overall survival [12]. On the contrary, Ekoue et al. published that GPX1 expression levels have no impact on survival in patients with prostatic adenocarcinoma [31].

From previous studies and our study, we noted that GPX1 functions with different behaviors based on the tumor type. Besides, the molecular basis of GPX1 needs to be more explored.

\section{Conclusions}

In conclusion, GPX1-mRNA high expression was noted in MPM and was linked to adverse prognosis and poor survival. It can be used as a possible biomarker for diagnosis and prognosis in MPM.

Author Contributions: Conceptualization A.F.G., E.M.E. and A.E.A.; methodology, N.R., A.S.K., W.H.E., M.A.S. and M.A.E.; original draft preparation, E.M.E., M.A.S. and N.R. writing-review and editing, M.A.E. and A.S.K.; project administration W.H.E. and A.F.G.; supervision, A.F.G. and R.A.E.; Validation, N.R. and R.A.E.; Funding, E.M.E. and A.E.A. All authors have read and agreed to the published version of the manuscript.

Funding: This study was funded by Taif University Researchers Supporting Project number (TURSP2020/157), Taif University Taif, Saudi Arabia.

Institutional Review Board Statement: Ethical committee of Zagazig University and the International Review Board (IRB), Faculty of Medicine, approved this study (Zu-IRB\#3266/19-9-2019).

Informed Consent Statement: Informed consent was obtained from all subjects involved in the study.

Data Availability Statement: Data available on request due to privacy/ethical restrictions.

Acknowledgments: The authors would like to extend their profound thanks to Taif University Researchers Supporting Project number (TURSP-2020/157), Taif, Saudi Arabia, for funding of this research.

Conflicts of Interest: The authors declare no conflict of interest.

\section{References}

1. Vogelzang, N.J.; Rusthoven, J.J.; Symanowski, J.; Denham, C.; Kaukel, E.; Ruffie, P.; Gatzemeier, U.; Boyer, M.; Emri, S.; Manegold, C.; et al. Phase III study of pemetrexed in combination with cisplatin versus cisplatin alone in patients with malignant pleural mesothelioma. J. Clin. Oncol. 2003, 21, 2636-2644. [CrossRef] [PubMed]

2. Borasio, P.; Berruti, A.; Billé, A.; Lausi, P.O.; Levra, M.G.; Giardino, R.; Ardissone, F. Malignant pleural mesothelioma: Clinicopathologic and survival characteristics in a consecutive series of 394 patients. Eur. J. Cardio-Thoracic Surg. 2008, 33, 307-313. [CrossRef] [PubMed]

3. Koksal, D.; Ozmen, O.; Demirag, F.; Bayiz, H.; Aydogdu, K.; Berkoglu, M.; Koyuncu, A. Prognostic factors in malignant pleural mesothelioma: A retrospective study of 60 Turkish patients. J. Cancer Res. Ther. 2015, 11, 216-222. [CrossRef]

4. Di Leva, G.; Garofalo, M.; Croce, C.M. MicroRNAs in cancer. Annu. Rev. Pathol. Mech. Dis. 2014, 9, 287-314. [CrossRef] [PubMed]

5. Brigelius-Flohé, R.; Maiorino, M. Glutathione peroxidases. Biochim. Biophys. Acta (BBA)-Gen. Subj. 2013, 1830, 3289-3303. [CrossRef]

6. Lubos, E.; Loscalzo, J.; Handy, D.E. Glutathione peroxidase-1 in health and disease: From molecular mechanisms to therapeutic opportunities. Antioxid. Redox Signal. 2011, 15, 1957-1997. [CrossRef] [PubMed]

7. Brigelius-Flohe, R.; Kipp, A. Glutathione peroxidases in different stages of carcinogenesis. Biochim. Biophys. Acta (BBA)-Gen. Subj. 2009, 1790, 1555-1568. [CrossRef] [PubMed]

8. Baliga, M.S.; Wang, H.; Zhuo, P.; Schwartz, J.L.; Diamond, A.M. Selenium and GPx-1 overexpression protect mammalian cells against UV-induced DNA damage. Biol. Trace Elem. Res. 2007, 115, 227-241. [CrossRef]

9. Liu, J.; Hinkhouse, M.M.; Sun, W.; Weydert, C.J.; Ritchie, J.M.; Oberley, L.W.; Cullen, J.J. Redox regulation of pancreatic cancer cell growth: Role of glutathione peroxidase in the suppression of the malignant phenotype. Hum. Gene Ther. 2004, 15, 239-250. [CrossRef] [PubMed] 
10. Baliga, M.S.; Diwadkar-Navsariwala, V.; Koh, T.; Fayad, R.; Fantuzzi, G.; Diamond, A.M. Selenoprotein deficiency enhances radiation-induced micronuclei formation. Mol. Nutr. Food Res. 2008, 52, 1300-1304. [CrossRef] [PubMed]

11. Guerriero, E.; Capone, F.; Accardo, M.; Sorice, A.; Costantini, M.; Colonna, G.; Castello, G. GPX4 and GPX7 over-expression in human hepatocellular carcinoma tissues. Eur. J. Histochem. 2015, 59, 2540. [CrossRef] [PubMed]

12. Lee, J.R.; Roh, J.-L.; Lee, S.M.; Park, Y.; Cho, K.-J.; Choi, S.-H.; Nam, S.Y.; Kim, S.Y. Overexpression of glutathione peroxidase 1 predicts poor prognosis in oral squamous cell carcinoma. J. Cancer Res. Clin. Oncol. 2017, 143, 2257-2265. [CrossRef] [PubMed]

13. Amin, M.B.; Edge, S.B.; Greene, F.; Byrd, D.R.; Brookland, R.K.; Washington, M.K.; Gershenwald, J.E.; Compton, C.C.; Hess, K.R.; Sullivan, D.C.; et al. The eighth edition AJCC cancer staging manual: Continuing to build a bridge from a population-based to a more "personalized" approach to cancer staging. CA Cancer J. Clin. 2017, 67, 93-99. [CrossRef] [PubMed]

14. West, H.J.; Jin, J.O. Performance status in patients with cancer. JAMA Oncol. 2015, 1, 998. [CrossRef]

15. Nagaraj, N.S.; Washington, M.K.; Merchant, B.N. Combined blockade of Src kinase and epidermal growth factor receptor with gemcitabine overcomes STAT3-mediated resistance of inhibition of pancreatic tumor growth. Clin. Cancer Res. 2011, 17, 483-493. [CrossRef] [PubMed]

16. Al-Karmalawy, A.A.; Elshal, M.F. Concanavalin-A shows synergistic cytotoxicity with tamoxifen via inducing apoptosis in estrogen receptor-positive breast cancer: In vitro and molecular docking studies. Pharm Sci. 2021. [CrossRef]

17. Ghanem, A.A.; Emara, H.A.; Muawia, S.; El Maksoud, A.I.A.; Al-Karmalawy, A.A.; Elshal, M.F. Tanshinone IIA synergistically enhances the antitumor activity of doxorubicin by interfering with the PI3K/AKT/mTOR pathway and inhibition of topoisomerase II: In vitro and molecular docking studies. New J. Chem. 2020, 44, 17374-17381. [CrossRef]

18. Eliaa, S.G.; Al-Karmalawy, A.A.; Saleh, R.M.; Elshal, M.F. Empagliflozin and Doxorubicin Synergistically Inhibit the Survival of Triple-Negative Breast Cancer Cells via Interfering with the mTOR Pathway and Inhibition of Calmodulin: In Vitro and Molecular Docking Studies. ACS Pharmacol. Transl. Sci. 2020, 3, 1330-1338. [CrossRef]

19. Tafani, M.; Sansone, L.; Limana, F.; Arcangeli, T.; De Santis, E.; Polese, M.; Fini, M.; Russo, M.A. The interplay of reactive oxygen species, hypoxia, inflammation, and sirtuins in cancer initiation and progression. Oxidative Med. Cell. Longev. 2016, 2016, 3907147. [CrossRef] [PubMed]

20. Filaire, E.; Dupuis, C.; Galvaing, G.; Aubreton, S.; Laurent, H.; Richard, R.; Filaire, M. Lung cancer: What are the links with oxidative stress, physical activity and nutrition. Lung Cancer 2013, 82, 383-389. [CrossRef] [PubMed]

21. Da Motta, L.L.; Müller, C.B.; De Bastiani, M.A.; Behr, G.A.; Franca, F.S.; Da Rocha, R.F.; Minotto, J.B.; Meurer, R.T.; Fernandes, M.; Roehe, A.; et al. Imbalance in redox status is associated with tumor aggressiveness and poor outcome in lung adenocarcinoma patients. J. Cancer Res. Clin. Oncol. 2014, 140, 461-470. [CrossRef]

22. Al-Karmalawy, A.A.; Khattab, M. Molecular modelling of mebendazole polymorphs as a potential colchicine binding site inhibitor. New J. Chem. 2020, 44, 13990-13996. [CrossRef]

23. Khattab, M.; Al-Karmalawy, A.A. Revisiting Activity of Some Nocodazole Analogues as a Potential Anticancer Drugs Using Molecular Docking and DFT Calculations. Front. Chem. 2021, 9, 92. [CrossRef] [PubMed]

24. Meng, Q.; Xu, J.; Liang, C.; Liu, J.; Hua, J.; Zhang, Y.; Ni, Q.; Shi, S.; Yu, X. GPx1 is involved in the induction of protective autophagy in pancreatic cancer cells in response to glucose deprivation. Cell Death Dis. 2018, 9, 1187. [CrossRef]

25. Dequanter, D.; Dok, R.; Koolen, L.; Poorten, V.V.; Nuyts, S. Prognostic significance of glutathione peroxidase levels (GPx1) in head and neck cancers. Front. Oncol. 2017, 7, 84. [CrossRef] [PubMed]

26. Han, J.J.; Xie, D.R.; Wang, L.L.; Liu, Y.Q.; Wu, G.F.; Sun, Q.; Chen, Y.X.; Wei, Y.; Huang, Z.Q.; Li, H.G. Significance of glutathione peroxidase 1 and caudal-related homeodomain transcription factor in human gastric adenocarcinoma. Gastroenterol. Res. Pract. 2013, 2013, 380193. [CrossRef] [PubMed]

27. Zmorzyński, S.; Świderska-Kołacz, G.; Koczkodaj, D.; Filip, A. Significance of polymorphisms and expression of enzyme-encoding genes related to glutathione in hematopoietic cancers and solid tumors. BioMed Res. Int. 2015, 2015, 853573. [CrossRef]

28. Metere, A.; Frezzotti, F.; Graves, C.E.; Vergine, M.; De Luca, A.; Pietraforte, D.; Giacomelli, L. A possible role for selenoprotein glutathione peroxidase (GPx1) and thioredoxin reductases (TrxR1) in thyroid cancer: Our experience in thyroid surgery. Cancer Cell Int. 2018, 18, 7. [CrossRef]

29. Cheng, Y.; Xu, T.; Li, S.; Ruan, H. GPX1, a biomarker for the diagnosis and prognosis of kidney cancer, promotes the progression of kidney cancer. Aging 2019, 11, 12165. [CrossRef]

30. Min, S.Y.; Kim, H.S.; Jung, E.J.; Jee, C.D.; Kim, W.H. Prognostic significance of glutathione peroxidase 1 (GPX1) down-regulation and correlation with aberrant promoter methylation in human gastric cancer. Anticancer Res. 2012, 32, 3169-3175. [PubMed]

31. Ekoue, D.N.; Ansong, E.; Hong, L.K.; Nonn, L.; Macias, V.; Deaton, R.; Rupnow, R.; Gann, P.H.; Kajdacsy-Balla, A.; Diamond, A.M. GPX1 localizes to the nucleus in prostate epithelium and its levels are not associated with prostate cancer recurrence. Antioxidants 2018, 7, 167. [CrossRef] [PubMed] 